Academy of Management Review

2008, vol 33, No. 4, 985-993

\title{
A DISCURSIVE PERSPECTIVE ON LEGITIMATION STRATEGIES IN MULTINATIONAL CORPORATIONS
}

EERO VAARA

Swedish School of Economics and Ecole de Management de Lyon JANNE TIENARI

Helsinki School of Economics 
Few studies have examined legitimation in multinational corporations from a discursive perspective. To complement the existing institutional literature, we adopt a critical discourse analysis perspective that allows us to examine the microlevel processes of discursive legitimation. We provide an example of a media textdealing with a production unit shutdown - to demonstrate how this perspective elucidates the various textual strategies used to legitimate multinational corporations' actions and their controversial consequences.

Legitimacy is a key issue in organizations in general (Phillips, Lawrence, \& Hardy, 2004; Suchman, 1995; Suddaby \& Greenwood, 2005) and in multinational corporations (MNCs) in particular (Geppert, 2003; Kostova \& Zaheer, 1999). Although organizational analyses traditionally have focused on the cognitive and normative bases of legitimacy (Scott, 1995; Suchman, 1995), recent studies have also taken up the discursive aspects of legitimation (Brown, 1998; Brown \& Jones, 2000; Creed, Scully, \& Austin, 2002; Phillips et al., 2004; Suddaby \& Greenwood, 2005). In particular, Phillips et al. (2004) have argued that discourses play a central role in the legitimation of institutional change and have outlined a model in which the dialectics of organizational actions and discourses lead to institutionalization. Suddaby and Greenwood (2005), in turn, have specified types of rhetorical strategy that actors can use in the legitimation of organizational and institutional change.

In the MNC context, primarily institutionally oriented scholars have examined legitimacy ${ }^{1}$ (Gardberg \& Fombrun, 2006; Geppert, 2003; Kostova \& Zaheer, 1999; Rodriguez, Uhlenbruck, \& Eden, 2005). Some scholars have also analyzed the socially constructed nature of legitimation in MNCs (Geppert, 2003; Kostova \& Zaheer, 1999). In a landmark theoretical study, Kostova and Zaheer (1999), for example, proposed that MNCs face three types of complexity - the legitimating environment, the organization, and the process of legitimation - and they distinguished between the legitimacy of the MNC as a whole and that of its parts. These scholars' analysis points out how specific corporate actions and issues can become politicized and how the legitimacy of these

\footnotetext{
${ }^{1}$ We are very grateful to the guest editors and three anonymous reviewers, whose insights greatly contributed to the development of this paper. We also wish to thank Niina Erkama, Jeff Hearn, Saku Mantere, Linda McKie, David Miller, Pekka Pa“ 1li, and Joanna Sinclair for their invaluable help.
} 
actions - as well as of the corporation as a whole - may be questioned. Geppert (2003), in turn, has provided a rare study dealing with the discursive side of legitimation in the MNC context. In his comparative institutional analysis, he suggests a political sensemaking approach and refers to stories used to legitimate or delegitimate specific ideas about global manufacturing, established decision-making premises, and specific nationally entrenched work paradigms.

Despite these advances, analyses that would highlight the concrete discursive strategies used to establish legitimacy for MNC actions are lacking. In particular, there is a paucity of perspectives that would allow one to examine the political aspects of discursive legitimation. In this paper we wish to complement the existing institutionally oriented studies by focusing attention on the textual strategies used to legitimate controversial actions in MNCs. For this purpose we adopt a critical discursive analysis (CDA) perspective (Fairclough, 2003; Wodak \& Meyer, 2002). Accordingly, we see discourses as linguistically mediated representations of the world (Fairclough, 2003) that play a fundamental role in MNCs. CDA is not the only discursive approach that could be applied in such analysis, but CDA scholars have made significant advances in the linguistic analysis of microlevel discursive strategies used to legitimate controversial actions (Rojo \& van Dijk, 1997; van Leeuwen \& Wodak, 1999). We argue that this kind of discursive perspective adds to existing research on legitimation and opens up new avenues for critical social analysis of MNCs.

Next we specify our critical discursive perspective on legitimation. This is followed by an illustrative example - a media text dealing with a production unit shutdown. With this example we demonstrate how the discursive perspective elucidates the various microlevel textual processes that legitimate particular kinds of social change in and around MNCs. Finally, we discuss the merits and limitations of this kind of discursive approach to legitimation.

\section{A DISCURSIVE PERSPECTIVE ON LEGITIMATION}

Discursive approaches have become increasingly popular in social research (for an overview, see van Dijk, 1997), including organization and management studies (Boje, 
Oswick, \& Ford, 2004; Grant, Hardy, Oswick, \& Putnam, 2004; Grant, Keenoy, \& Oswick, 1998; Parker, 1992). In particular, CDA, in recent years, has developed into an established cross-disciplinary approach to linguistic analysis of social phenomena (Fairclough, 2003; Wodak \& Meyer, 2002). CDA also has inspired organization and management scholars to call for critically oriented organizational discourse analyses (Fairclough, 2005; Hardy, Palmer, \& Phillips, 2000; Mumby, 2004; Phillips et al., 2004; Thomas, 2003).

CDA involves a built-in critical stance. This is manifested in a conscious attempt to use discourse analytical tools for controversial social or societal issues. In particular, CDA examines the role of discourse in the social constitution of power relations and structures of domination in contemporary society (Fairclough, 1989, 2003; van Dijk, 1998). Although CDA scholars see discourses as central social practices, they emphasize the interplay of discourses, other social practices, and material conditions in discursive social analysis (Fairclough, 2003, 2005). Methodologically, CDA scholars underscore the importance of studying texts as concrete instances of discourse use and of analyzing the microlevel linguistic elements therein. Fairclough (2003) argues that discourses should ideally be analyzed simultaneously at three levels: text (microlevel textual elements), discursive practice (the production and interpretation of texts), and social practice (the situational and institutional context).

From this perspective, legitimation stands for creating a sense of positive, beneficial, ethical, understandable, necessary, or otherwise acceptable action in a specific setting (van Dijk, 1998; van Leeuwen \& Wodak, 1999). Legitimation is seen as a central process that deals with the specific issue or action in question, but it has more fundamental social and societal implications (van Dijk, 1998; van Leeuwen \& Wodak, 1999). While traditional rhetorical theories of legitimation focus on a specific issue that needs to be legitimated by the speaker, a critical perspective emphasizes that the legitimation of particular actions also deals with broader social practices and the power relations of the social actors involved (Rojo \& van Dijk, 1997; van Dijk, 1998). This links legitimation to ongoing political struggles in specific organizational and societal contexts. In an illuminating study of the micropolitics of legitimation, Rojo and van Dijk point out that legitimation has both a "top-down" and a "bottom-up" direction: "the 
(dominant) group or institution seeking to legitimate itself through approval from the dominated, and the dominated group legitimating the dominant group or institution through various forms of more or less active agreement, acceptance, compliance or at least tacit consent" (1997: 528).

In the MNC context this means that specific "legitimacy crises" (Kostova \& Zaheer, 1999) not only are separate incidents but also deal with important questions concerning established social practices and institutions, as well as the power relations of the actors involved. We previously analyzed the foreign acquisition of a state-owned Norwegian bank (Tienari, Vaara, \& Björkman, 2003). The public discussion was not only about the legitimacy of the particular acquisition but also about foreign ownership in general in the previously nationally controlled sector. The discussion in the media was characterized by complex discursive dynamics that could only be understood by realizing that the power positions of both politicians and corporate representatives were at stake.

From a discursive perspective, the starting point for any analysis of legitimation is the notion that senses of legitimacy are created in relation to specific discourses: discourses provide the "frames" with which people make sense of particular issues and give sense to them (e.g., Fairclough, 1989, 1992; Fiss \& Hirsch, 2005). These framings have important implications for the actors involved. On the one hand, the available discourses greatly constrain specific actors when making sense of and giving sense to particular actions. In fact, particular discourses enable only certain kinds of subject positions or warrant voice for particular concerns (e.g., Fairclough, 1992; van Leeuwen \& Wodak, 1999). On the other hand, actors can also purposefully position themselves visa -vis specific discourses or mobilize particular discourses for their own advantage (e.g., Hardy et al., 2000; Rojo \& van Dijk, 1997).

Discourses are ideologically laden, and, therefore, legitimation necessarily involves reproduction of ideologies (van Dijk, 1998).1 Van Dijk goes so far as to state that "legitimation is one of the main social functions of ideologies" (1998: 255). This means that in a very concrete sense specific discussions around controversial actions are also ideological struggles.

In the MNC context we often observe particular kinds of struggles. In these struggles controversial actions are frequently linked with neoliberal or global capitalist 
(Fairclough, 2006) ideologies. ${ }^{2}$ Within such a discursive framework, MNC-driven changes are often legitimated as a "necessity" in global competition, even if they involve problematic social consequences in local settings (Fairclough \& Thomas, 2004). However, there are also other ideologies that tend to play an important role in MNCs. For example, radical humanist or Marxist discourses are frequently employed to resist the neoliberal world order (Held, McGrew, Goldblatt, \& Perraton, 1999). Nationalism provides another important set of discourses (Anderson, 1983; Hobsbawm, 1990; Wodak, de Cillia, Reisigl, \& Liebhart, 1999) used to make sense of important issues in MNCs. Legitimation in the MNC context thus usually entails complex interdiscursive dynamics where specific discourses and ideologies provide alternative and often competing ways to legitimate or delegitimate particular actions.

The specific nature of these discursive struggles depends on context. Hodge and Coronado (2006) provide an illuminating example of such struggles. In their analysis of the Mexican government's Plan-Puebla-Panama (a policy document dealing with the southeast region of Mexico), they show how the discourse on economic reform involved a "complex" of global capitalist and nationalist discourses and ideologies that was used to legitimate the opening of the Mexican market for foreign-based MNCs. Interestingly, the government's discourse included many contradictory elements that were nevertheless used in the same text to legitimate the reform.

An essential part of CDA is examining the specific ways in which legitimation is carried out. In CDA this has been conceptualized in terms of "legitimation strategies"in other words, specific ways of mobilizing specific discursive resources to create a sense of legitimacy or illegitimacy (Fairclough, 2003: 98-100; van Dijk, 1998: 255-262). In the most salient cases the use of these discursive strategies can be very conscious and planned. However, this is not always the case. For example, people sometimes revert to available discourses almost "automatically," as in the case of "banal nationalism" (Billig, 1995) or "uncritical globalism" (Fairclough, 2006). Furthermore, particular genres, such as business news, are characterized by specific conventions regarding what can or should

2 In this view "ideologies are representations of aspects of the world which can be shown to contribute to establishing, maintaining and changing social relations of power, domination and exploitation" (Fairclough, 2003: 9). 2 Neoliberalism, which can take many forms, can be seen as a political project with the aim of removing obstacles to full implementation of the global economy. Global capitalism is a pro-globalization ideology, the various forms of which are mediated by context-specific discourses (Fairclough, 2006). 2008 Vaara and Tienari 987 
be said and how it should be said (e.g., Fairclough, 2003). These conventions greatly affect the use of particular legitimation strategies in a given setting. The point is that in CDA one is able to examine not only the "obvious" rhetorical legitimation acts but also the more subtle ways in which specific discursive functions and practices are used to establish or resist legitimacy in a particular text.

Drawing from van Leeuwen's earlier work on the "grammar of legitimation," van Leeuwen and Wodak (1999) distinguished and elaborated on specific legitimating strategies. According to these researchers, there are four general types of semanticfunctional strategy - that is, ways in which language functions and is used for the construction of legitimacy. Authorization is legitimation by reference to the authority of tradition, custom, law, and persons in whom institutional authority of some kind is vested. Rationalization is legitimation by reference to the utility of specific actions based on knowledge claims that are accepted in a given context as relevant. Moral evaluation is, in turn, legitimation by reference to specific value systems that provide the moral basis for legitimation. Finally, mythopoesis is legitimation conveyed through narratives. This means telling stories or constructing narrative structures to indicate how the issue in question relates to the past or the future. Each of the four general types of semanticfunctional strategy includes a number of subtypes, the relevance of which naturally depend on the setting in question. Importantly, legitimation strategies are usually intertwined in specific texts, and multiple legitimation is often the most effective form of legitimation.

In the MNC context there are very few examples of analysis of such legitimation strategies. Elsewhere, we examined the discursive legitimation of a cross-border merger (Vaara, Tienari, \& Laurila, 2006). By drawing on van Leeuwen's work, we identified five types of legitimation strategy-normalization, authorization, rationalization, moralization, and narrativization - that were used for the legitimation or delegitimation of the merger. We distinguished normalization as a separate category of authorization to emphasize the importance of strategies used to render specific actions or phenomena "normal" or "natural."

All in all, this kind of discursive approach allows one to focus attention on the processes of legitimation in and around MNCs by examining the discourses mobilized 
and the strategies used. It allows a shift in focus from established senses of legitimacy to ongoing discursive struggles for legitimation and, thus, increases our understanding of the microlevel political dynamics of these processes.

\section{EXAMPLE: LEGITIMATING A SHUTDOWN IN THE MEDIA}

Our example deals with a media text that helps to illuminate how a controversial action and its consequences are legitimated by subtle textual strategies. A discursive perspective can, however, also be applied to many other kinds of texts: corporate or government communications (Hodge \& Coronado, 2006; Rojo \& van Dijk, 1997), textbooks and other material intended for learning and education (Fairclough, 2003; Kilduff \& Kelemen, 2004), and various kinds of naturally occurring talk in organizations (Potter \& Wetherell, 1987).3

Our example focuses on a media text concerned with a production unit shutdown. Shutdowns related to transfers of production are prime examples of the controversial effects of MNC-driven globalization. These actions, however, have received very little attention in previous research (for a review, see Hirsch \& De Soucey, 2006). The case in question is the shutdown of a long-standing marine engine factory in the city of Turku, Finland, carried out by Wärtsila * Group in 2004 and 2005. Watseka's decision to move engine production to Trieste, Italy, had drastic effects on unemployment in the Turku region. This case is distinguished by the fact that the unit in Turku had not been unprofitable. In the Finnish context, where consensus-based industrial relations traditionally have prevented corporations from making such moves, this decision was unprecedented (Vaara \& Erkama, 2005).

The following text illustrates how the shutdown was initially presented in the leading Finnish daily newspaper, Helsingin Sanomat ${ }^{3}$, which can be seen as an opinion leader in the Finnish media. This reporting created a specific sense of legitimacy around the controversial decision and set the tone for the subsequent public discussion.

\footnotetext{
3 Furthermore, MNC research itself can be examined from a critical discursive perspective-for example, in the sense of its cultural imperialist or neocolonial assumptions (e.g., Banerjee \& Linstead, 2001; Lorbiecki \& Jack, 2000; Prasad, 2003; Westwood, 2001). 988 Academy of Management Review October
} 
Wärtsila“ moves its engine manufacturing to Italy $4 \mathbf{4 8 0}$ people lose their jobs, 200 maintenance men remain in Turku Capacity is cut to improve profitability

The engine manufacturer Wärtsilä will shut down its long-standing factory in Turku and move its production to Trieste, Italy. Of the 680 employees in Turku, 480 will lose their jobs. A couple of hundred people will retain their jobs in diesel engine maintenance service. About 130 of those who are going to lose their jobs will have an opportunity for early retirement; 350 employees will be dismissed. Production will be transferred to Italy in the fall.

The CEO of Wärtsilä, Ole Johansson, says that engine production in Vaasa [another Finnish city] will continue as before. There are 1,600 employees in Vaasa and about 1,200 in Trieste. Vaasa is the technology and R\&D center for the entire Wärtsila“ Group.

According to Johansson, the shutdown is not due to a lack of competitiveness in Turku. He says that the multinational has only bad alternatives since overcapacity has to be cut because of weak demand. This shutdown will, according to Johansson, secure full employment in Vaasa and Trieste.

The shutdown is part of Wärtsilä's restructuring program, which was started last September. The group will reduce its workforce by a total of 1,100 people. On Wednesday it was announced that a total of 70 people would be made redundant in Norway and Holland. Johansson estimated that the shutdown of the Turku factory would affect "a few dozen jobs" with subcontractors in the Turku region.

Johansson argues that concentration of large engine production at Trieste is justified because the factory is Wärtsilä's largest. Concentration will create flexibility for changes in demand. While two different engine types are manufactured in Turku, several are made in Trieste, including those made in Turku.

When demand is strong, a factory like Turku is effective, but it becomes problematic when the market slows down. Last year people in Turku faced temporary layoffs. Trieste does not require large investments, as is the case in 
Turku, where more production capacity is needed. Trieste also has direct access to natural gas, which is needed for testing gas engines.

"This solution will significantly increase the profitability of the multinational corporation," Johansson estimates. The share price of the corporation increased after the shutdown news. According to Johansson, restructuring production will generate annual savings of approximately 60 million euros, which will affect earnings from 2005 onwards (Helsingin Sanomat, January $15,2004)$.

This news report is a typical example of a discursive struggle over shutdowns. The genre of the focal text is business news, but the text is also an approving commentary on the "official"information given by Wärtsila" 's corporate communications. The text thus represents a hybrid genre, typical of contemporary media (Fairclough, 1995; van Dijk, 1990). On the whole, global capitalist discourse is the dominant discourse used; it provides the primary framework to make sense of the controversial decision. Several legitimation strategies are used. To a large extent, the text rests on the authorization provided by CEO Ole Johansson. The involvement of the CEO lends credibility to the evidence provided, most clearly shown in his speech acts. However, the journalist composing and editing the text also uses other means of authorization. Importantly, the reference to the increase in share price serves as a particularly powerful legitimation strategy. In a sense, the "market" acts as the ultimate authority in contemporary global capitalism (for similar findings, see Vaara et al., 2006).

Various rationalization strategies are also used. Financial rationalization plays an accentuated role: the shutdown is legitimated by references to profitability improvement and annual savings. This is the case even though the CEO admits that the "competitiveness" of the unit is not a problem per se. This is one of the most striking features of this text-improvement of future profitability, rather than current problems, is the main reason given for the shutdown. In this sense the text deals with "imaginaries" (Fairclough \& Thomas, 2004) or "futurological prediction" (Fairclough, 2003). The modality of the text is a significant part of the rationalization. For example, the claim that 
"overcapacity has to be cut" is portrayed as an obligation ${ }^{4}$ in terms of the future success of the MNC, leaving no room for alternative scenarios.

Defining the Wärtsilä Group as an MNCmakes all the difference in the text. This framing legitimates the shutdown by appealing to the effect it will have on the overall profitability of the corporation. This is a key theme in the text, and it is explicitly spelled out in the final comment of the CEO: "This solution will significantly increase the profitability of the multinational corporation." From other media texts published-for example, in the local newspaper-we learn that this is in stark contrast to the view held by people in Turku (Vaara \& Erkama, 2005), who saw the factory (and the company itself) as an integral part of the shipbuilding tradition in the Turku region since the late eighteenth century. From this perspective, shutting down the unit-especially since it was profitable_- did not make any sense.

"Overcapacity" is a particularly interesting rationalization theme in the text. It nominalizes a state of affairs accepted as fact. It also involves discursive "technologization" (Fairclough, 1995: 91-111), in the sense that grasping the issue at hand ("overcapacity") is difficult without detailed knowledge of the industry dynamics. What happened in the previous year - the "temporary layoffs"-is also used as evidence here. Other rationalizations include pointing out that the unit in Trieste is larger than the one in Turku, that the Trieste unit allows for better concentration of production, and that it provides more access to necessary natural resources. "Concentration" and "flexibility" are interesting themes in this respect. They are often used by decision makers in MNCs to create a positive sense of the prospects for reorganizing production across national borders.

Moralization strategies are also used in the text. While the beginning of the text effectively raises doubts concerning the moral basis of the shutdown decision by pointing to dramatic job losses, the latter part of the text echoes the official corporate view. An important part of legitimation is that the eventual unemployment of the workers in Turku is necessary so that workers in Vaasa and Trieste will have "full employment." As a linguistic detail, the verb "secure" is used as a particularly forceful confirmation. The

\footnotetext{
4 Translating texts from one language into another involves complicated challenges. Meanings may be unwittingly transformed or lost in the process. We have translated this media text and the following analysis from Finnish to English with the help of a native English speaker who is fluent in Finnish.
} 
reference to Vaasa is crucial from a nationalistic Finnish perspective, since it justifies the layoffs in one location by the "fact" that this will allow the other unit in Finland to survive. Taking up the layoffs in other countries (Norway and Holland) then serves as a justification of processual fairness. The significance of job losses elsewhere in the Turku region, for example, in relation to the MNC's subcontractors, is played down (only "a few dozen jobs" will be lost). It is, however, the apparent inevitability of the situation"we have only bad alternatives"- that serves as the overarching moralization strategy in the text.

Finally, there are interesting mythopoetical elements in the text. There is a "restructuring program" already under way in the MNC, and the shutdown decision is an essential part of this program. The restructuring program can be seen as a euphemism for layoffs, and its narrative construction makes it a self-justifying structure. The shutdown becomes a strategic - not a haphazard-one-off decision. This attaches an additional sense of inevitability to this particular decision.

We can thus see how particular discursive strategies are used to legitimate a change with significant social and material consequences: transfer of production and loss of jobs. Importantly, the legitimation process in shutting down the Turku unit had ramifications beyond the boundaries of the MNC in question. Wärtsila". 's move was soon followed by other corporations that have traditionally refrained from shutdowns of profitable units in Finland (Vaara \& Erkama, 2005). In this sense the discursive struggle in the Wärtsila“ case was about the right of Finnish-based MNCs to engage in shutdowns of profitable units - an action that had not previously been considered possible in Finland. In the CDA spirit we are thus able to comprehend the broader relevance of this kind of action for the fundamental redefinition of the social responsibility of MNCs, in this case in Finnish society.

\section{DISCUSSION AND CONCLUSION}

We know a great deal about legitimacy in management and organizations (Suchman, 1995), but the discursive aspects of legitimation have remained underexplored (Phillips et al., 2004; Suddaby \& Greenwood, 2005). This is especially the case with 
MNC research, where in previous analyses scholars have paid little attention to discursive legitimation processes and practices (Geppert, 2003; Kostova \& Zaheer, 1999). Hence, in this paper we have suggested a microlevel discursive perspective to complement the existing institutional research. We have argued that CDA provides a useful-albeit not the only possible - approach to critically oriented analysis of controversial MNC actions. Through our media text example we have illustrated how this approach helps to focus on the micro level of legitimation and to reveal such textual dynamics that have passed unnoticed in previous research.

In particular, our analysis demonstrates the central role of discursive strategies such as authorization, rationalization, moralization, and mythopoesis (van Leeuwen \& Wodak, 1999) as concrete means through which controversial actions are legitimated in the MNC context. Paying attention to these textual strategies is important since it allows us to see how senses of legitimacy are created and manipulated at the textual level. This perspective thus adds to previous studies that have not specified the concrete ways in which specific ideas and practices are legitimated in communication in and around MNCs (Geppert, 2003; Kostova \& Zaheer, 1999). Mapping out the microelements also makes it possible to uncover complexities, ambiguities, and contradictions in legitimation processes that have, on the whole, received little attention in previous studies (Hodge \& Coronado, 2006; Vaara et al., 2006). Furthermore, this analysis helps us understand the inherent political nature of such discursive legitimation: it is through subtle textual strategies that particular interests and voices are reproduced and others silenced. This political side is not trivial and certainly not to be taken lightly when considering the various kinds of controversial actions in which MNCs are engaged.

This approach can be applied to many kinds of MNC actions. However, it is particularly useful for examining actions that have problematic social implications. In this sense this discursive approach can specifically advance critically oriented MNC studies. Shutdowns constitute one important topic that has not received sufficient attention in previous MNC research (Hirsch \& De Soucey, 2006). Other important but neglected topics include environmental problems (Livesey, 2002; Prasad \& Elmes, 2005), cultural imperialism (Jack, 2004; Prasad, 2003), racism (Nkomo, 1992; Potter \& Wetherell, 1992), and gender inequality (Cala’'s \& Smircich, 1993). 
We have offered a critical reading of a specific text. By so doing, we have elucidated the central role of texts in legitimation and institutionalization processes in MNC and other contexts. In particular, CDA clarifies the linkages between microlevel textual processes and functions and macrolevel social phenomena that have not been adequately specified in previous research (Phillips et al., 2004). This does not mean, however, that CDA should always focus on individual texts. On the contrary, CDA can well be applied to larger sets of texts. In that case the application of CDA involves strategic choices in terms of selection of texts, appropriate methods of analysis to be applied, and textual examples to be analyzed in more detail (Vaara \& Tienari, 2004).

Although we have specified and exemplified the role of textual strategies in the legitimation of MNC actions, there are issues that should be elaborated in future research. We have not focused here on intertextuality - that is, on the linkages between specific texts in discussions around particular phenomena. Yet this is a central issue in terms of being able to map out the impact of specific texts on others in legitimation processes (e.g., van Leeuwen \& Wodak, 1999). Our analysis has highlighted the inherent politics of legitimation, but the dialectics of legitimation and its resistance deserve more attention in future research (e.g., Mumby, 2004). Interdiscursivity-the interplay of different discourses and ideologies in texts (e.g., Fairclough, 2003; Hodge \& Coronado, 2006)—is another important issue that needs attention in future analyses of legitimation. Thus, we believe that this paper has merely opened up a theoretical view that could be extended further.

Finally, this approach involves specific challenges that should be taken seriously. The ideal in CDA is to engage in "transdisciplinary research efforts," where the skills and ideas of linguists and social scientists such as international management scholars are combined (Fairclough, 2005). This, however, is not easy to accomplish. In practice, it is also hard to study small pieces of text in great linguistic detail while mapping out the more general social dynamics in question. Researchers also need to deal with cumbersome questions of text selection and generalization in such analyses. Despite these challenges, we believe that this kind of CDA has a great deal to offer. We hope that this paper will promote discursive studies of MNCs and will, in general, encourage 
international management scholars to engage in critically oriented analysis of social change in and around MNCs.

\section{REFERENCES}

Anderson, B. 1983. Imagined communities: Reflections on the origin and spread of nationalism. London: Verso Editions \& NLB. Banerjee, S. B., \& Linstead, S. 2001. Globalization, multiculturalism and other fictions: Colonialism for the new millennium? Organization, 8: 683-722.

Billig, M. 1995. Banal nationalism. London: Sage. Boje, D. M., Oswick, C., \& Ford, J. D. (Eds.). 2004. Language and organization: The doing of discourse. Academy of Management Review, 29: 571-577.

Brown, A. 1998. Narrative, politics and legitimacy in an IT implementation. Journal of Management Studies, 35: 35-58.

Brown, A. D., \& Jones, M. R. 2000. Honourable members and dishonourable deeds: Sensemaking, impression management and legitimation in the "Arms of Iraq Affair." Human Relations, 53: 655-690.

Cala' s, M. B., \& Smircich, L. 1993. Dangerous liaisons: The "feminine in management" meets “globalization.” Business Horizons, 36(2): 73-83.

Creed, D., Scully, M., \& Austin J. 2002. Clothes make the person? The tailoring of legitimating accounts and the social construction of identity. Organization Science, 13: $475-496$.

Fairclough, N. 1989. Language and power. London: Longman.

Fairclough, N. 1992. Discourse and social change. Cambridge:Polity Press. 
Fairclough, N. 1995. Media discourse. London: Edward Arnold.

Fairclough, N. 2003. Analysing discourse: Textual analysis for social research. London: Longman.

Fairclough, N. 2005. Discourse analysis in organization studies: The case for critical realism. Organization Studies, 26: 915-939.

Fairclough, N. 2006. Language and globalization. London: Routledge.

Fairclough, N., \& Thomas, P. 2004. The discourse of globalization and the globalization of discourse. In D. Grant, C.

Hardy, C. Oswick, \& L. Putnam (Eds.), The Sage handbook of organizational discourse: $379-396$. London: Sage.

Fiss, P. C., \& Hirsch, P. M. 2005. The discourse of globalization: Framing and sensemaking of an emerging concept. American Sociological Review, 70: 29-52.

Gardberg, N. A., \& Fombrun, C. J. 2006. Corporate citizenship: Creating intangible assets across institutional environments. Academy of Management Review, 31: 329-346.

Geppert, M. 2003. Sensemaking and politics in MNCs: A comparative analysis of vocabularies within the global manufacturing discourse in one industrial sector. Journal of Management Inquiry, 12: 312-329.

Grant, D., Hardy, C., Oswick, C., \& Putnam, L. (Eds.). 2004. Organizational discourse. London: Sage.Grant, D., Keenoy, T., \& Oswick, C. (Eds.). 1998. Discourse _ organization. London: Sage. 
Hardy, C., Palmer, I., \& Phillips, N. 2000. Discourse as a strategic resource. Human Relations, 53: 1227-1248.

Held, D., McGrew, A., Goldblatt, D., \& Perraton, J. 1999. Global transformations. Cambridge: Polity Press.

Hirsch, P., \& De Soucey, M. 2006. Organizational restructuring and its consequences: Rhetorical and structural. Annual Review of Sociology, 32: 171-189.

Hobsbawm, E. 1990. Nations and nationalism since 1780. Cambridge: Cambridge University Press.

Hodge, B., \& Coronado, G. 2006. Mexico Inc.? Discourse analysis and the triumph of managerialism. Organization, 13: 529-547.

Jack, G. 2004. Guest editorial: Languages, intercultural communication and the machinations of global capital: Towards a dialectical critique. Language and Intercultural Communication, 4(3): 121-133.

Kilduff, M., \& Kelemen, M. 2004. Deconstructing discourse. In D. Grant, C. Hardy, C. Oswick, \& L. Putnam (Eds.), The Sage handbook of organizational discourse: 259-272.

London: Sage. Kostova, T., \& Zaheer, S. 1999. Organizational legitimacy under conditions of complexity: The case of the multinational enterprise. Academy of Management Review,24: 64-81.

Livesey, S. M. 2002. Global warming wars: Rhetorical and discourse analytic approaches to Exxonmobil's corporate public discourse. Journal of Business Communication, 39: $117-146$. 
Lorbiecki, A., \& Jack, G. 2000. Critical turns in the evolution of diversity management. British Journal of Management, 11(Special Issue): 17-31.

Mumby, D. 2004. Discourse, power and ideology: Unpacking the critical approach. In D. Grant, C. Hardy, C. Oswick, \& L. Putnam (Eds.), The Sage handbook of organizational discourse: $237-258$. London: Sage.

Nkomo, S. M. 1992. The emperor has no clothes: Rewriting "race in organizations." Academy of Management Review, 17: 487-513.

Parker, M. 1992. Discourse dynamics. London: Routledge. Phillips, N., Lawrence, T. B., \& Hardy, C. 2004. Discourse and institutions. Academy of Management Review, 29: $635-652$.

Potter, J., \& Wetherell, M. 1987. Discourse and social psychology. London: Sage.

Potter, J., \& Wetherell, M. 1992. Mapping the language of racism: Discourse and legitimation of exploitation. London:Harvester Wheatsheap.

Prasad, A. (Ed.). 2003. Postcolonial theory and organizational 992 Academy of Management Review October analysis: A critical engagement. New York: Palgrave Macmillan.

Prasad, P., \& Elmes, M. 2005. In the name of the practical: Unearthing the hegemony of pragmatics in the discourse of environmental management. Journal of Management Studies, 42: 845-867.

Rodriguez, P., Uhlenbruck, K., \& Eden, L. 2005. Government corruption and the entry strategies of multinationals. Academy of Management Review, 30: 383-396. 
Rojo, L., \& van Dijk, T. 1997. “There was a problem, and it was solved!”: Legitimating the expulsion of "illegal" migrants in Spanish parliamentary discourse. Discourse \& Society, 8: 523-566.

Scott, W. R. 1995. Institutions and organizations. Thousand Oaks, CA: Sage.

Suchman, M. C. 1995. Managing legitimacy: Strategic and institutional approaches. Academy of Management Review, 20: 729-757.

Suddaby, R., \& Greenwood, R. 2005. Rhetorical strategies of legitimacy. Administrative Science Quarterly, 50: 35-67.

Thomas, P. 2003. The recontextualization of management: A discourse-based approach analyzing the development of management thinking. Journal of Management Studies, 40: 775-801.

Tienari, J., Vaara, E., \& Bjo"rkman, I. 2003. Global capitalism meets national spirit: Discourses in media texts on a cross-border acquisition. Journal of Management Inquiry, 12: 377-393.

Vaara, E., \& Erkama, N. 2005. On the darker side of industrial restructuring: A critical media analysis of shutdown decisions. Paper presented at the annual meeting of the European Group for Organizational Studies, Berlin.

Vaara, E., \& Tienari, J. 2004. Critical discourse analysis as methodology for critical international business studies. In R. Marschan-Piekkari \& C. Welch (Eds.), Handbook of qualitative research methods for international business: $342-362$.

London: Edward Elgar. Vaara, E., Tienari, J., \& Laurila, J. 2006. Pulp and paper fiction: On the discursive legitimation of global industrial restructuring. Organization Studies, 27: 789-810. 
van Dijk, T. 1990. News as discourse. Hillsdale, NJ: Lawrence Erlbaum Associates. van Dijk, T. 1997. Discourse studies: A multidisciplinary introduction, vols. 1 \& 2. London: Sage.

van Dijk, T. 1998. Ideology: A multidisciplinary approach.London: Sage.

van Leeuwen, T., \& Wodak, R. 1999. Legitimizing immigration control: A discoursehistorical perspective. Discourse Studies, 1: 83-118.

Westwood, R. 2001. Appropriating the other in the discourses of comparative management. In R. Westwood \& S. Linstead (Eds.), The language of organization: 241282. London: Sage.

Wodak, R., de Cillia, R., Reisigl, M., \& Liebhart, K. 1999. The discursive construction of national identity. Edinburgh: Edinburgh University Press.

Wodak, R., \& Meyer, M. 2002. Methods of critical discourse analysis. London: Sage. 
Eero Vaara (eero.vaara@hanken.fi) is professor of management and organization at the Swedish School of Economics, Finland, and permanent visiting professor at Ecole de Management de Lyon, France. He received his Ph.D. from the Helsinki School of Economics. His research interests include radical organizational change, strategyaspractice, multinational corporations, and philosophical and methodological issues in organization and management research.

Janne Tienari (janne.tienari@hse.fi) is professor of management and organizations at the Helsinki School of Economics, Finland. He received his Ph.D. from the Helsinki School of Economics. His research interests include managing multinational corporations, cross-cultural studies of gender and organizing, and media discourse. 